\title{
'n Nuwe parallelle Nuwe Testament in Afrikaans
}

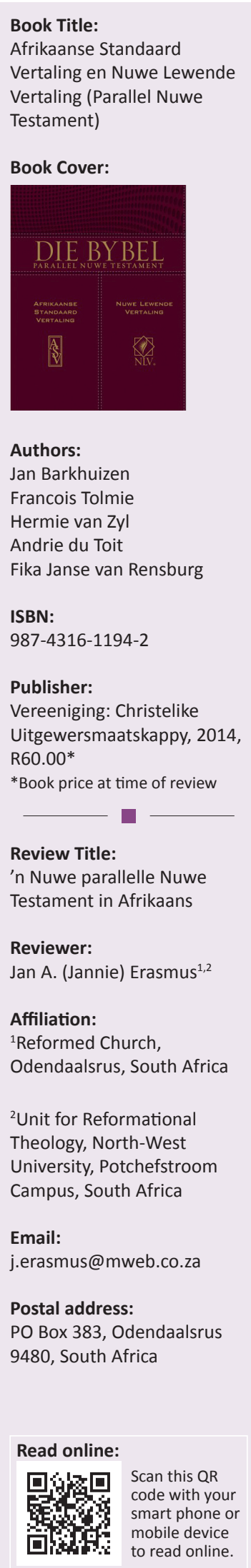

Die Bybel - Afrikaanse Standaard Vertaling en Nuwe Lewende Vertaling (Parallel Nuwe Testament) is 'n publikasie van die Christelike Uitgewersmaatskappy waarin hulle die teks van twee vertalings van die Nuwe Testament parallel langs mekaar plaas. Die vertalings wat langs mekaar geplaas word, is die Nuwe Lewende Vertaling en die Afrikaanse Standaard Vertaling wat albei deur die Christelike Uitgewersmaatskappy uitgegee word. Hierdie vertalings is nie deur die Bybelgenootskap gedoen nie en is dus addisionele vertalings in Afrikaans.

Die Christelike Uitgewersmaatskappy het die Nuwe Lewende Vertaling oorspronklik in 2006 uitgegee en in 2011 hersien. Die vertaalfilosofie van hierdie vertaling kan as dinamies-ekwivalent beskryf word. Dit beteken dat, alhoewel die grondteks sover moontlik gevolg word, die hooffokus is om die boodskap van die teks duidelik in Afrikaans te vertaal. Die implikasie hiervan is dat daar soms ingrypend van die letterlike grondteks afgewyk moet word sodat dit in Afrikaans verstaanbaar kan wees (vgl. Matt 7:6).

Die Afrikaanse Standaard Vertaling het sy oorsprong in die Interliniêre Bybel wat in 2012 deur Christelike Uitgewersmaatskappy uitgegee is. Die Afrikaanse Standaard Vertaling is 'n produk van die hersiening van die direkte vertaling wat in die Interliniêre Bybel gedoen is. Alhoewel die vertaling dus die hooffokus op die brontaal het, word met die sinvolheid in Afrikaans rekening gehou (vgl. weer eens die vertaling van die Griekse chiasma in Matt 7:6). Lesers moet egter nie hierdie direkte vertaling met Die Bybel - 'n Direkte Vertaling verwar waarmee die Bybelgenootskap tans besig is, en waarvan ' $n$ proefuitgawe van die Nuwe Testament en Psalms in 2014 verskyn het nie.

Afrikaanse lesers van die Bybel is baie bevoorreg om in 'n tyd te leef waarin daar soveel verskillende vertalings van die Bybel in Afrikaans beskikbaar is. Die gebruik van 'n verskeidenheid vertalings beteken dat daar soveel beter vasgestel kan word wat die presiese bedoeling of boodskap van 'n Bybelteks is. Die waarde van Die Bybel - Afrikaanse Standaard Vertaling en Nuwe Lewende Vertaling (Parallel Nuwe Testament) is dat dit twee vertalings direk langs mekaar plaas, wat die vergelyking tussen hierdie vertalings baie vergemaklik. Die publikasie maak ook ruimskoots van voetnote gebruik om nog verdere verheldering van sake te bied.

Die leefwêreld van die Nuwe Testament is soms baie vreemd vir die mens van die eenen-twintigste eeu. Vreemde geldeenhede, mates, titels, ensovoorts het tot gevolg dat die Bybelteks soms ver van ons eie leefwêreld verwyderd voel. Deur 'n direkte vertaling en 'n dinamiesekwivalente vertaling langs mekaar te plaas, en nog verdere inligting deur middel van voetnote te voorsien, help dat die leefwêreld van die Nuwe Testament skielik nie meer so vreemd voel nie, maar dat dit vir die Afrikaanse leser meer duidelik en toepaslik word (vgl. die gebruik van die term denarii in Mark 6:37).

Daar kan baie gesprek oor die gebruik van geslagsinklusiewe aanspreekvorms in die Nuwe Lewende Vertaling gevoer word, maar deur in hierdie parallelle Nuwe Testament die Afrikaanse Standaard Vertaling daarnaas te plaas, word perspektief aan die bybelse kulturele gebruik verleen om meestal net met die manlike geslag te praat (vgl. Rom 12:1). Weer eens help die parallelle plasing van die twee vertalings om enersyds die Bybelteks duidelik te maak, maar andersyds om die boodskap vir vandag toepaslik te maak.

Een leemte van hierdie publikasie is dat die titel, volgens die resensent, nie heeltemal korrek is nie. Die Bybel bestaan immers uit die Ou en die Nuwe Testament en hierdie publikasie bevat slegs die Nuwe Testament. Om in 'n groot drukgrootte die naam, Die Bybel, op die voorblad

How to cite this book review: Erasmus, J.A., 2015, "n Nuwe parallelle Nuwe Testament in Afrikaans', In die Skriflig 49(1), Art. \#1998, 2 pages. http://dx.doi.org/10.4102/ids.v49i1.1998

Copyright: (C) 2015. The Authors. Licensee: AOSIS OpenJournals. This work is licensed under the Creative Commons Attribution License. 
te druk, en dan in heelwat kleiner drukgrootte die woorde Parallel Nuwe Testament daaronder te druk, kan potensiële lesers aanvanklik verwar.

'n Verdere verwagting waaraan nie vir die resensent voldoen is nie, is dat 'n publikasie wat in die verlede slegs die Nuwe Testament bevat het, dikwels ook die boek van die Psalms daarmee saam uitgegee het-en dit is nou nie die geval nie. Die Psalms is poësie en om die oorspronklike Hebreeuse poësie in duidelike Afrikaans te vertaal, is nie maklik nie. Deur ' $n$ direkte vertaling van die Psalms parallel met 'n dinamiesekwivalente vertaling te publiseer, sou groot waarde aan hierdie publikasie toegevoeg het. Hopelik is hierdie parallelle Nuwe Testament die aanvoorwerk vir 'n ware parallelle Bybel wat die volle Ou en Nuwe Testament bevat.
Die publikasie word in twee weergawes uitgegee. Daar is 'n sagtebanduitgawe sowel as 'n luukse leeruitgawe met duimdrukke, merklint en goudgerande bladsye. Albei weergawes word teen 'n billike prys aangebied. Die meeste Afrikaanse lesers van die Bybel sou die publikasie kon aanskaf om hulle Bybellees te verruim.

Hierdie parallelle Nuwe Testament is by uitnemendheid daarvoor geskik om saam met ander vertalings van die Bybel gebruik te word. Vir persoonlike sowel as groepsbybelstudie sal hierdie boek 'n waardevolle hulpmiddel wees om nog beter insig in die boodskap van die Bybel te verkry. Hierdie publikasie word van harte vir elke ernstige leser en student van die Bybel aanbeveel. 